\title{
PROBLEMS OF PUBLIC ADMINISTRATION IN THE UNITED TERRITORIAL COMMUNITIES IN UKRAINE
}

Actualization of the problem. The implementation of the decentralization reform in Ukraine is entering the final phase of creating about 1,500 united territorial communities (in Ukrainian OTG) throughout the country. However, the current phase of the completion of the creation of the OTG revealed a number of problematic issues, the relevance of which increases as new ones are created, and as a result of the full-value functioning of the already created the OTGs. The problems that fell out of the attention of the developers of decentralization reform are becoming apparent. The most important of them is the striking inequality in the initial conditions for the formation of the OTG, which became clear only now, after two or three years of functioning of the created OTG, especially of the rural type. The decisive motive for the creation of the OTG over the entire period starting in 2015 is the expectation of a better, in comparison with the current administrative system, financing of primary communities. The budget of any OTG for the first time is formed taking into account direct subventions from the general budget of Ukraine, which ensure the functioning of health care and educational institutions, partly also - the development of the OTG itself from centralized sources. However, the second part of the OTG budget is made up of own funds earned by the OTG itself on the basis of centrally established by the state norms for deductions from taxes, excise duties etc. Expectations of their own source of development and improvement of the living standards of residents are connected with this part of the OTG's own budget. However, the available data indicate a huge difference in the amounts of income earned by different OTGs. Thus, in the most successful OTG, own funds in the community budget per resident reach $15-18$ thousand hryvnias, and on average in the country - less than three [1]! In the Troitska OTG of Luhansk oblast there are 7 thousand own funds per inhabitant, and only a little more than two thousand per inhabitant of the neighbor's Chmyrivska one.

The decentralization reform in Ukraine is carried out, first of all, as a budget one. However, in fact, in the OTG a fundamentally new paradigm of the position of a person as a member of society is formed, which had no analogues in the system of the former administrative model: district - settlement-personality. The success of the community cannot be achieved without taking into account the role of the individual person - a participant of the OTG as a self-sufficient business entity. And on the other hand, OTG should provide every person with the development opportunities, the potential of which is formed by the very status of this new administrative unit.

Unfortunately, the authors of the decentralization reform did not provide for the necessary symbiosis of new human capabilities in the OTG and the sources of his self-development. Under the current conditions, there is a «vacuum» of public administration on the part of the OTG leadership, which has limited opportunities to influence income growth, to assist its residents in initiating entrepreneurial activities, and to take an active part in managing the community. The management apparatus itself in most rural OTGs is formed by analogy with previously existing village councils, in which it is impossible to implement full-fledged public management of the community, covering setting goals for their development, planning and financial support for their achievements, organizing feedback and motivation population to perform common tasks, effective control and regulation of planned processes. It is the results of the analysis of the problems of public administration in the OTG that the present article is devoted to.

Analysis of materials, which demonstrate the process of understanding the issues of public administration in the OTG. The fundamentals of decentralization reform in Ukraine, which were scattered by the low sovereign bodies and the huge bodies, fully were built on the positive growth in foreign countries, in particular, Denmark, Norway, Poland etc, mostly represented in numerous publications, for example [2]. The powers of local self management at the beginning of the reform of decentralization in Ukraine are disclosed in the monograph [3], development and implementation of projects in the public sphere is in the work [4], implementation of national regional policy is in the work [5]. But in fact, as a result of analysis of the process of creation and activity of the OTG [6], most attention of decentralization theorists and practitioners in Ukraine is paid to the issues of budgetary decentralization, the most of the works devoted to the creation of the OTG in Ukraine such as [7]. As a result, in the process of building the OTG in Ukraine, a new type of budget type was implemented in the framework of the model of 
budgetary unitarity, which is carried out in the largest countries of Europe. Theoretical points of public administration in the OTG at the most general form is regulated by the Law of Ukraine "On the principles of state regional policy" [8], which outlines the order of power division in Ukraine into two branches - state government and local self management, but without clear reflection of the governance features that emerge from reform at the lower level of the administrative system.

The Law of Ukraine «On the Principles of State Regional Policy» provides for the establishment of special regional development agencies, co-founded by regional chambers of commerce and industry, regional associations of entrepreneurs, regional representations of all-Ukrainian associations of local self management, associations of local self management of the region etc. However, the two-stage process of creation of the OTG in Ukraine, when at the first stage, the OTGs were created voluntarily according to the Law of Ukraine «On Voluntary Amalgamation of Territorial Communities» [9], led to a delay of the whole process of administrative decentralization, when for the mass of technical details of creation of the OTG there was a problem of management within them which fell out of the attention of the creators of the OTG.

Awareness of the issue of public administration in the OTG becomes evident as a result of the first years functioning of the already created territorial associations. For example, the authority of a number of the OTGs in Luhansk oblast, who have been working for 2-3 years, note the insufficiency of their own means of managing the development of the production base inside the OTG, without which their financial recovery is impossible. Thus, in Krasnorichinsk community with 7 thousand people, they protect youth from outflow, as a potential power, which is able to create new farming or participate in its work. The main issue of these problems is to ensure the participation of the OTG in the implementation of the program for developing entrepreneurship as a part of the assistance of the United Nations and different foundations with the financial support of foreign countries [10]. This incentive to encourage entrepreneurship remains a major source in a number of other communities in the Luhansk oblast. The head of the «Kreminska Business Association» said that for the development of business in the OTG there was not enough information and mutual understanding with the authorities, which at the grassroots level of the administrative structure of the country did not fully understand the benefits of cooperation with businessmen [11]. Therefore, as the problems that hinder the development of the domestic OTGs become more and more important, there is an increasing awareness of the existence of a certain «vacuum» of public-private management within the OTGs, which is the topic of this article.
The purpose of the article is to show the results of the analysis and identification of actual issues of public administration development within the OTG.

Outline of the main material of the article. Ukraine carries out its decentralization almost the last of the Eastern European countries, using the positive foreign experience, most of all - Poland, as the closest large country, with which Ukraine shares a common history, and many quantitative parameters.

Analyzing the legislation on the decentralization of Ukraine, it is clear that the image of Poland's three-level administrative system «voivodship-county-gmina» was taken as a model, however, the final parameters of the administrative restructuring, which is still incomplete, still differ from the Polish one.

So far, 25 regions remain in Ukraine with 16 voivodships in Poland, however, administrative units of the middle and lower links in Ukraine are formed on a larger scale. There should be approximately 100 districts, which are supposed to be reorganized in the regions, in the presence of 380 counties in Poland, and the number of units of the lower level - amalgamated hromads 1,500 instead of almost 2,500 in Poland.

Taking into account the large territory of Ukraine, the area of formed self-managed administrative units is much larger. The question arises about the completeness of the competence that local authorities in the Ukrainian OTG should have, including in comparison with Polish gminas. This issue should be considered in the context of the expected results of the completion of the administrative reform of decentralization.

In the existing system, the executive agencies of the lower-level settlements - towns of regional subordination, urban villages, villages are located at the lower level of the three - or even four-level executive branch system. In such circumstances, the decision of many issues of self-management in the lower-level communities is undertaken by the executive agencies of higher administrative units - the district in the town, district and region. As a result of the reform of decentralization, the whole range of issues of self-management in the lower-level communities falls on their own executive agencies, except for tasks which are solved jointly with the executive agencies of the higher links.

Actually, several hundred existing united territorial communities have actually encountered the peculiarities of self-management in the new conditions. The selfmanagement in the OTG is practically becoming autonomous, and all participation of higher levels of management is reduced to a system of forming the OTG budgets at the expense of centralized budget subventions and own funds. The funds of state subventions for the functioning of the health care and education sectors, as well as the funds of the regional development fund, are set by the state budget for the next calendar year and cannot serve as a source of financing the development of the OTG in other areas. 
Own funds of the OTG are formed on a single regulatory framework, including about 40 sources, the most important of which are:

$60 \%$ of the individual income tax;

$100 \%$ of the property tax;

$100 \%$ of the single tax;

$5 \%$ of the excise tax on retail (tobacco and alcohol products, petroleum products);

$100 \%$ of the tax on profit of enterprises and public utilities of the OTG;

$100 \%$ of payments for the provision of administrative services;

$25 \%$ of the environmental tax.

The possibility of expanding the basis for the formation of its own part of the OTG budget and its effective use forms the tasks of the executive branch within the community as an object of public administration. An analysis of the results of the OTG functioning, the dynamics of their indicators, allows to judge the unavailability of public administration within the OTG to solve the tasks. The published materials of numerous analyzes of the OTG work in different regions of the country, the data obtained from the study of the state of OTG of Luhansk oblast indicate that the OTG, for the most part, is not able to seriously influence the processes of its own development and remain hostages to the conditions in which they were created.

The decisive indicator, which proves the low dynamics of the development of the OTG, is the share of own revenues earned by the OTG per resident.

Let's present the data in the table on the amount of own income and share of income per resident for some OTG.

Data on the number and income of the OTG

\begin{tabular}{|c|c|c|c|c|c|c|}
\hline Name of the OTG & Region & $\begin{array}{l}\text { Reporting } \\
\text { period }\end{array}$ & $\begin{array}{l}\text { Number of } \\
\text { inhabit- } \\
\text { ants, } \\
\text { thousand } \\
\text { people }\end{array}$ & $\begin{array}{c}\text { Own in- } \\
\text { come of } \\
\text { the OTG, } \\
\text { thous. } \\
\text { UAH }\end{array}$ & $\begin{array}{c}\text { Own income } \\
\text { per one resi- } \\
\text { dent of the } \\
\text { OTG, thous. } \\
\text { UAH }\end{array}$ & Source \\
\hline 1 & 2 & 3 & 4 & 5 & 6 & 7 \\
\hline Troitska & Dnipropetrovsk & 9 & 2,7 & 48330 & 17,9 & [1] \\
\hline Senchanska & Poltava & months & 3 & 50100 & 16,7 & [1] \\
\hline Slobozhanska & Dnipropetrovsk & 2018 & 14,6 & 229220 & 15,7 & [1] \\
\hline Boratynska & Volyn & year & 7,5 & 94380 & 12,1 & [1] \\
\hline Verbkivska & Dnipropetrovsk & - & 7,5 & 84000 & 11,2 & [1] \\
\hline Oliivska & Zhytomyr & - & 5,3 & 58300 & 11,0 & [1] \\
\hline Bohdanivska & Dnipropetrovsk & - & 6,8 & 74120 & 10,9 & [1] \\
\hline Shakhivska & Donetsk & - & 2,9 & 31030 & 10,7 & [1] \\
\hline Stepanetska & Cherkasy & - & 5,3 & 55650 & 10,5 & [1] \\
\hline Hrechanopodivska & Dnipropetrovsk & - & 3,6 & 37440 & 10,4 & [1] \\
\hline Troitska & Luhansk & 2018 & 14,1 & 97871 & 6,9 & [12] \\
\hline Chmyrivska & Luhansk & 2019 & 7,68 & 16468 & 2,14 & [13] \\
\hline
\end{tabular}

Significant differences in the amount of the OTG own income per inhabitant for different territorial communities indicate not so much the different level of quality of self-management in the OTG, but the difference in the initial conditions for creating the OTG. Let us note several reasons explaining the various results of the OTG activity.

1. OTGs were in the most favorable position, on the territory of which there are larger communal enterprises and budgetary institutions, as the Individual Income Tax (IIT) are protected by more than $50 \%$ of the total revenues from the OTG. Whereby, the higher the salaries of employees of enterprises and institutions, the greater the amount of contributions to the community budget. In other words, the advantage was found in the OTG, created on the basis of more developed industrial and agro-industrial areas.
2. Serious differences in the initial conditions are noted for the OTG, which were created at the first stage by voluntary association, and those that now have to be created by force. During 4 years of decentralization reform, the legislation was constantly improved and supplemented, in particular, starting in spring of 2018, it became possible to create the OTG based on the unification of villages and urban villages together with nearby towns of regional subordination. For small settlements near such cities, more attractive opportunities for unification appeared [14], while the settlements that had created the OTG before the adoption of this Law lost this opportunity.

3. On the contrary, the negative factor is the proximity of the OTG to the large industrial cities if they divert the activities of the residents of neighboring OTG, created from relatively weaker in terms of industrial development of settlements and villages. In general, the 
system of the OTG creation there is their division into those that attract the attention and participation in the activities of residents of the other OTGs (let's call them OTG-recipients), and on the other hand - those whose activities are carried out outside the OTG (let's call them OTG-donors). As a result, there are already significant trends in impoverishment of the OTG-donors and, on the contrary, enrichment of the OTG-recipients. It means that usual, as under the conditions of the past administrative structure, the participation of a resident of any settlement in the activities of another, which did not cause any impact on their relations before, leads to the creation of new effects, which are reflected in the formation and use of budgets. The usual manifestations of a person's life in the conditions of the OTG affect the formation of income and expenditure of their budgets. Thus, the work of residents of villages and urban villages adjacent to larger settlements, including towns outside the OTG, means payment of individual income tax (IIT) to the OGT-recipient's budget. The purchase of fuel at gas stations, other goods and services also increases the revenues of the OTG-recipient in the form of excise taxes and taxes. At the same time, residents of the OTG-donor use the results of community activities at the expense of their own earned money. In such an unenviable position was Chmyrivska OTG of Luhansk region, located near the larger town Starobilsk, where many residents of the villages which belong to Chmyrivska hromada, work. It is no coincidence that Chmyrivka, which is the typical OTG-donor, earns the smallest amount of its own income per resident, while Ttoitsk OTG's income per resident is higher, because it does not feel the influence from being near the larger town.

The pattern of formation of OTG recipients and OTG donors is shown in the figure.

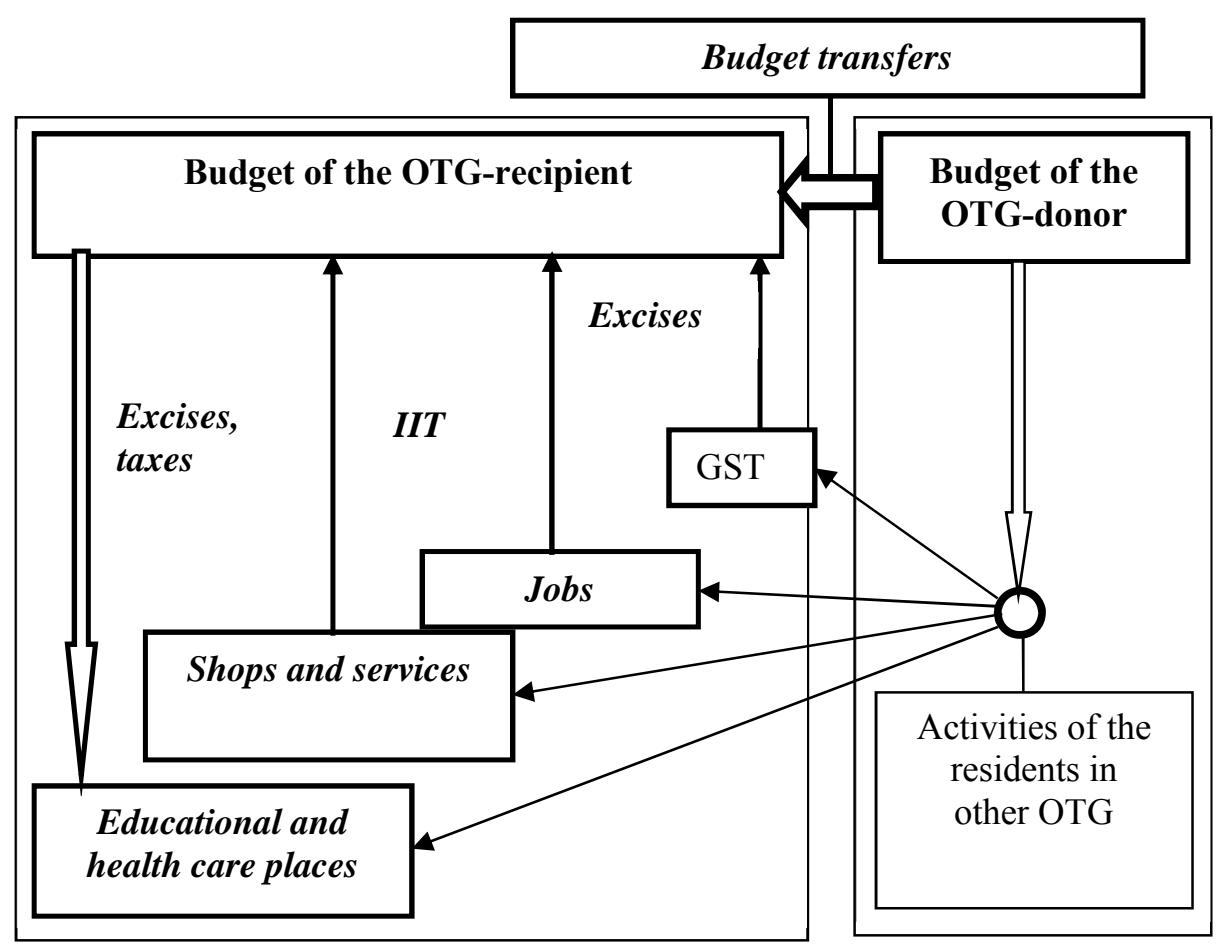

Figure. Scheme of donor and recipient OTG formation through participation of residents of some communities in the activities of others (GST - gas stations; IIT - individual income taxes)

4. Neither the developers of the decentralization reform, nor the creators of the first OTGs took into account the inevitable enlargement of districts, their transformation into counties with new administrative centers, with the inevitable change in the status of former district centers and the procedure for their centralized financing from the country's budget. For example, the town Starobilsk, previously a district center, having become the center of Starobilsk community, receives a state subvention for education and medical care not for the entire district, as before, but only on the basis of the number of residents of Starobilsk community. As a result, Starobilsk OTG is now invoicing for payment to neighboring
OTG, whose residents are served in medical facilities in Starobilsk.

5. It is known that OTG took over thousands of institutions of education, culture, and health care with their centralized funding from subventions from the country's budget. At the same time, it is not taken into account that hospital counties with new medical centers are being created by the health care reform, and the financing of the small medical institutions in OTG falls on their shoulders.

Overcoming these negative phenomena requires effective public administration, the tools of which for such objects as the united territorial community are still 
being developed. Keep in mind that public administration, as part of the general theory of management, is nevertheless different from classical management, whose objects - organizations and enterprises - are deterministic systems with a certain set of elements. Public administration in OTG cannot be carried out in the form of administrative management, but rather in the form of economic management, when set goals and objectives are solved by means of stimulation and accounting results based on developed feedback [15].

Accordingly, the deterministic plans in OTG typical for management are replaced with open offers in the form of motivational offers that take into account the prevailing archetypes of population behavior in this OTG based on stable traditions, upbringing, regional peculiarities, etc. Thus, public administration in OTG should implement certain paradigms of activity, designed for different segments of the population. So, for the population of agricultural regions of the north of the Luhansk region, such stereotypes of behavior are simultaneously characteristic, as:

work in other regions of the country and abroad while maintaining the constancy of the place of residence in his OTG;

the desire to develop their own business in the form of farms, especially family type;

obtaining education and subsequent work in nearby larger settlements, etc.

Given these archetypes, for example, development programs for farming within the OTG should be developed, which has a significant impact on the own revenues of the OTG budget, namely - a single income from entrepreneurial activity, $60 \%$ tax on personal income, property tax, in particular, land.

Such programs should persuade farmers not to transfer their activities to other territorial communities on their own motives, thereby changing the recipient of these payments. Particular, attention should be paid to family farms (FF), which are least likely to change their habitat. So far, programs provided by the UN and various funds with financial support from foreign countries remain the main source of agricultural development. But already, OTG executives are seeing a decrease in external assistance and see the need to create a favorable public environment within the OTG to stimulate entrepreneurs, in particular, through the use of best practices from foreign countries to stimulate entrepreneurial activity at the expense of their own communities.

The analysis of the world experience shows that it is within the local self-government bodies that they develop their own system of measures to stimulate entrepreneurial activity, in particular for the initiators of the creation of new FF, for young farmers under 40 years of age and others [16]. In order to improve their self-financing, it is better to anticipate some costs for setting up new farms to compensate for them over time by increasing the revenue from the activity of the created business objects. Thus, it may be expedient to pay for the development of the first hectares of arable land, discounts to the payment of taxes to farms when increasing their production volumes, the introduction of zero and reduced rates of taxation of young farmers, improvement of land relations within OTG for their preparation for leasing new farmers, assistance in state registration of created objects.

Conclusions. An analysis of existing OTG and the process of completing their creation shows that for the success of the decentralization reform it is necessary to overcome the problems that arise within the created OTG. The traditional relations "society-personality", "leadership-population" inside the OTG do not meet the requirements that form the nature of self-governing administrative and economic units, which become the OTG. This makes the task of forming a modern public administration system within communities capable of recognizing the causes of emerging problems, timely responding to them and developing measures to prevent negative trends, encouraging community members to work for the common good, including by allocating budget funds for farming development and other types of entrepreneurship/

The necessity of legislative regulation of the problem of unequal conditions of formation of OTG, should not be excluded.

\section{Literature}

1. Дуб А. Рейтинг богатейших ОТГ, или где в Украине жить хорошо / Ліга. Бизнес. 20.02.2019. URL: https://biz.liga.net/all/all/article/reyting-bogateyshih-otgili-gde-v-ukraine-jit-horosho. 2. Ткачук А. Місцеве самоврядування та децентралізація. Практичний посібник / Швейцарсько-український проект «Підтримка децентралізації в Україні - DESPRO». Київ: ТOB «Софія». 2012. 120 с. 3. Ганущак Ю. Реформа територіальної організації влади; Швейцарсько-український проект «Підтримка децентралізації в Україні DESPRO». Київ: TOB «Софія-А». 2013. 160 с. 4. Чемерис А. Розроблення та управління проектами у публічній сфері: європейський вимір для України. Практичний посібник / Швейцарсько-український проект «Підтримка децентралізації в Україні - DESPRO». Київ: ТОВ «Софія-А». 2012. 80 с. 5 . Ткачук А.Ф. Державна регіональна політика від асиметрії до солідарності (робочий зошит). Київ: ІКЦ «Легальний статус», 2013.112 с. 6. Куценко Т.Ф., Дударенко Є.Ю. Об'єднані територіальні громади в Україні: короткий аналітичний огляд. Економіка та держава, № 3, 2017. С. 6470. URL: http://www.economy.in.ua/?op $=1 \& z=3720 \& \mathrm{i}=$ 12. 7. Пріоритети реформування та напрями перспективного розвитку міжбюджетних відносин в умовах бюджетної децентралізації в Україні. Київ: НІСД, 2015. 80 с. 8. Закон України «Про засади державної регіональної політики». Відомості Верховної Ради України. 2015. № 13. Ст. 90. URL: https://zakon.rada.gov.ua/ laws/show/156-19. 9. Закон України "Про добровільне об’єднання територіальних громад". Відомості Вер- 
ховної Ради Украӥни. 2015. № 13. Ст. 91. URL: https: //zakon.rada.gov.ua/laws/show/157-19. 10. Як Красноріченська громада вирішує свої проблеми (відео). Трибун. 11.11.2019. URL: https://tribun.com.ua/63662?fbclid =IwAR2D_a35z6a0UgE4gKQdtLmITX3ZrxJ7iBNEwcw _IWh7BF9vfcIkhi4Jdp8. 11. Глава "Кременской бизнес ассоциации" рассказал, чего не хватает предпринимателям Луганщины. Трибун. Общественно-политический обозреватель. Медіа-платформа "Діалог». 05.11.2019. URL: https://tribun.com.ua/63508. 12. Tроїцька територіальна громада, Луганська область, Троїцький район. URL: https://troicka-gromada.gov.ua/. 13. Чмирівська громада, Луганська область, Старобільський район. URL: https://chmyrivska-gromada.gov. ua/. 14. Дубровык-Рохова А. Громады смогут присоединяться к городам областного значения. День. 2018. № 60. 5 апреля. URL: https://day.kyiv.ua/ru/article/ ekonomika/gromady-smogut-prisoedinyatsya-k-gorodamoblastnogo-znacheniya. 15. Колосов А.М., Коваленко О.В., Кучеренко С.К., Бикова В.Г. Економічне управління підприємством : навч. посіб. / за заг. ред. А. М. Колосова. Старобільськ: Вид-во держ. закл. «Луган. Нац. Ун-т імені Тараса Шевченка», 2015. 352 с. 16. Малік М. Й., Шпикуляк О. Г., Мамчур В. А. Інституційна формалізація розвитку сімейних фермерських господарств в Україні. Економіка АПК. 2018. №10. C. 72-85. URL: http://nbuv. gov.ua/UJRN/E_apk_ 2018 10_11.

\section{References}

1. Dub A. (2019). Reiting bogateishih OTG, ili, gde v Ukraini zit horosho [Rating of the richest OTG, or where in Ukraine to live well]. Liga. Biznes - League. Business. 20.02.2019. Retrieved from https://biz.liga.net/all/all/article/reyting-bogateyshih-otg-ili-gde-v-ukraine-jit-horosho [in Ukrainian].

2. Tkachuk A. (2012). Misceve samovriaduvannia ta decentralizacyja. Praktychnyi posibnyk [Local selfgovernment and decentralization. A practical guide] / Shvejcarsko-ukrainskyj proekt «Pidtrymka decentralizaciji v Ukraini - DESPRO»-Swiss-Ukrainian project "Support for decentralization in Ukraine - DESPRO”. Kyiv, TOV «Sofija-A». 120 p. [in Ukrainian].

3. Ganushiak Ju. (2013). Reforma terytorialnoji organizacyji vlady [Reform of the territorial organization of power] / Shvejcarsko-ukrainskyj proekt «Pidtrymka decentralizaciji V Ukraini - DESPRO» - Swiss-Ukrainian project "Support for decentralization in Ukraine DESPRO”. Kyiv, TOV «Sofija-A». 160 p. [in Ukrainian].

4. Chemerys A. (2012). Rozroblennia ta upravlinnia proektamy u publichnij sferi [Public project development and management: a European dimension for Ukraine. A practical guide] / Shvejcarsko-ukrainskyi proekt «Pidtrymka decentralizaciji v Ukraini - DESPRO» - SwissUkrainian project "Support for decentralization in Ukraine - DESPRO”. Kyiv, TOV «Sofija-A». 80 p. [in Ukrainian].

5. Tkachuk A. (2013). Derzhavna regionalna polityka vid asymetriji do solidarnosti (robochyi zoshyt) [State regional policy from asymmetry to solidarity (workbook)]. Kyiv, IKC «Legalnyi status». 112 p. [in Ukrainian].
6. Kucenko T., Dudarenko Je. (2017). Objednani terytorialni gromady $\mathrm{v}$ Ukraini: korotkyi analitychnyi ogliad [United territorial communities in Ukraine: a brief analytical review]. Ekonomika ta derzhava - Economy and the state, 3, pp. 64-70. Retrieved from http://www.economy.in.ua/?op=1\&z=3720\&i=12 [in Ukrainian].

7. Priorytety reformuvannia ta napriamy perspektyvnogo rozvytku mizhbiudzhetnyh vidnosyn $\mathrm{v}$ umovah biudzhetnoji decentralizaciji v Ukraini [Reform priorities and directions for perspective development of intergovernmental budgetary relations in the context of decentralization in Ukraine]. Kyiv, NISD. 80 p. [in Ukrainian].

8. Zakon Ukrainy «Pro zasady derzhavnoji regionalnoji polityky» [Law of Ukraine "On the Principles of State Regional Policy"]. Vidomosti Verhovnoji Rady Ukrainy Sheets of the Supreme Rada of Ukraine, № 13, art. 90. Retrieved from https://zakon.rada.gov.ua/laws/show/156-19 [in Ukrainian].

9. Zakon Ukrainy "Pro dobrovilne objednannia terytorialnyh gromad" [Law of Ukraine «About voluntary association of territorial communities»]. Vidomosti Verhovnoji Rady Ukrainy - Sheets of the Supreme Rada of Ukraine, № 13, art. 91. Retrieved from https://zakon.rada.gov.ua/laws/show/157-19 [in Ukrainian].

10. Jak Krasnorichenska gromada vyrishuje svoji problem (video) [How the Krasnorichenska community solves its problems (video)]. Trybun - Tribune. 11.11.2019. Retrieved from https://tribun.com.ua/63662 ?fbclid=IwAR2D_a35z6a0UgE4gKQdtLmITX3ZrxJ7iB NEwcwIWh7B F9vfcIkhi4Jdp8.

11. Glava «Kremenskoj biznes associaciji» rasskazal, chego ne hvataet predprinimateliam Luganshiny [The head of the "Kremennaja Business Association" told what the entrepreneurs of Lugansk region lack]. Трибун - Tribun. 05.11.2019. Retrieved from https://tribun.com.ua/63508. [in Russian].

12. Troicka terytotialna gromada, Luhanska oblast, Troickii rajon [Troicke territorial community, Luhansk region, Troicke district]. Retrieved from https://troickagromada.gov.ua// [in Ukrainian].

13. Chmyrivska gromada, Luhanska oblast, Starodilskyi rajon [Chmirivka territorial community, Luhansk region, Starobilsk district]. Retrieved from https: //chmyrivska-gromada.gov.ua/ [in Ukrainian].

14. Dubrovyh-Rohova A. (2018). Gromady smogut prisojediniatsia $\mathrm{k}$ gorodam oblastnogo znachenija [Communities will be able to join the cities of regional significance]. Gazeta «Den»-The newspaper "Day", № 60, 05.04.2018. Retrieved from https://day.kyiv.ua/ru/article/ ekonomika/gromady-smogut-prisoedinyatsya-k-gorodamoblastnogo-znacheniya [in Russian].

15. Kolosov A., Kovalenko O., Kucherenko S., Bykova V. (2015). Ekonomichne upravlinnia pidpryjemstvom : navchalnyi posibnyk [Economic management of the enterprise: a textbook] / Starobilsk, «Lugansk nacionalnyi universitet imeni Tarasa Shevchenka». 352 p. [in Ukrainian].

16. Malik M., Shpykuliak O. Mamchur V. (2018). Instytucijna formalizacija rozvytku simejnyh fermerskyh gospodarstv v Ukraini [Institutional formalization of the 
development of family farms in Ukraine]. Ekonomika $A P K$ - APK Economy, № 10, pp. 72-85. Retrieved from http:/ /nbuv. gov.ua/UJRN/E_ apk_ 2018 _10_11 [in Ukrainian].

Савченко О. С. Проблематика публічного управління в об'сднаних територіальних громадах в Україні

Аналіз діючих об'єднаних територіальних громад (ОТГ) і процесу завершення їх створення показує наявність серйозних проблем, що виникають всередині ОТГ як через нерівномірність початкових умов їх створення, так і через неготовність їх керівництва до нових умов публічного управління всередині громад. Показано, що традиційні відносини «суспільство-особистість», «керівництво-населення» всередині ОТГ не відповідають вимогам, які формує сама природа ОТГ, як самоврядних адміністративних одиниць. Традиційні прояви людей-членів ОТГ, пов'язані з їх від'їздом, роботою, покупками і користуванням послугами в інших ОТГ, призводять до зменшення доходів ОТГ, в яких вони проживають, чим обумовлюється поява ОТГ-донорів і ОТГ-реципієнтів.

Це робить актуальним завдання формування сучасної системи публічного управління всередині громад, здатної усвідомлювати причини проблем, своєчасно на них реагувати і розробляти систему заходів запобігання негативним тенденціям і заохочення членів громад до праці на загальну користь, у тому числі за рахунок виділення спеціальних коштів бюджету на розвиток фермерства та інших видів підприємництва в ОТГ.

Ключові слова: підприємництво, адміністративна реформа, об'єднана територіальна громада, спроможність громади, фермерське господарство.

Savchenko A. Problems of Public Administration in the United Territorial Communities in Ukraine

An analysis of the existing united territorial communities (OTG) and the process of completion of their creation shows the presence of serious problems arising inside the OTG as a result of unequal initial conditions for their creation, and because of the unwillingness of their leadership to the new conditions of public administration within communities. It is shown that the traditional relations "society-personality", "leadership-population" within the OTG are not correspond to the requirements that form the very nature of OTG as self-governing administra- tive units. The traditional manifestations of the people who are members of OTG related to their departure, work, shopping and using services in other OTGs lead to a decrease in the incomes of the OTGs in which they live, which determines the appearance of OTG-donors and OTG-recipients.

This makes it urgent to create a modern public administration system within communities that is able to recognize the causes of emerging problems, respond to them in a timely manner, prevent negative trends and encourage community members to work for the common good, including by allocating special budget funds for farming development and others types of entrepreneurship in OTG.

Keywords: entrepreneurship, administrative reform, united territorial community, community viability, farming.

Савченко А. С. Проблематика публичного управления в объединенных территориальных громадах в Украине

Анализ действующих объединенных территориальных громад (ОТГ) и процесса завершения их создания показывает наличие серьезных проблем, возникающих внутри ОТГ как по причине неравномерных начальных условий их создания, так и из-за неготовности их руководства к новым условиям публичного управления внутри громад. Показано, что традиционные отношения «общество-личность», «руководствонаселение» внутри ОТГ не соответствуют требованиям, которые формирует сама природа ОТГ, как самоуправляемых административных единиц. Традиционные проявления людей-членов ОТГ, связанные с их отъездом, работой, покупками и пользованием услугами в других ОТГ, приводят к уменьшению доходов ОТГ, в которых они проживают, чем обусловливается появление ОТГ-доноров и ОТГ-реципиентов.

Это делает актуальной задачу формирования современной системы публичного управления внутри громад, способной осознавать причины возникающих проблем, своевременно на них реагировать и разрабатывать систему мер предотвращения негативных тенденций и поощрения членов общин к труду на общую пользу, в том числе за счет выделения специальных средств бюджета на развитие фермерства и других видов предпринимательства в ОТГ.

Ключевые слова: предпринимательство, административная реформа, объединенная территориальная громада, состоятельность громады, фермерское хозяйство.

Received by the editors: 29.11.2019

and final form 19.12.2019 